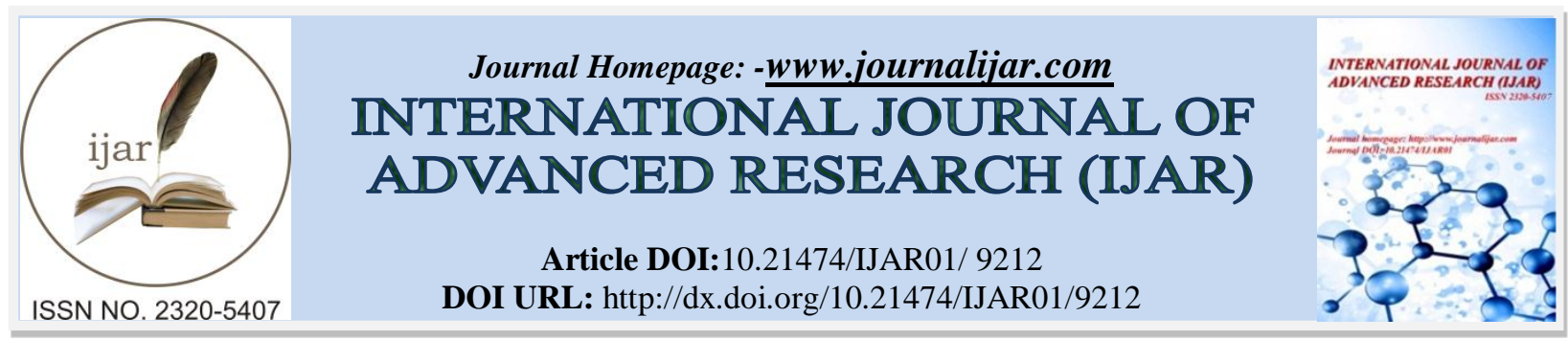

RESEARCH ARTICLE

\title{
EFFECTIVENESS OF STRUCTURED TEACHING PROGRAMME ON KNOWLEDGE AND EXPRESSED PRACTICE REGARDING SANITARY NAPKIN AMONG SCHOOL GIRLS THOSE WHO ATTAINED MENARCHE AT A SELECTED SCHOOL IN KANCHEEPURAM DISTRICT.
}

DR.T.komalavalli ${ }^{1}$ and Mrs.M.Saritha ${ }^{2}$.

1. M.Sc(N).,Ph.d., principal.,Karpaga Vinayaga college of nursing,chinnakolambakkam,kancheepuram dt.

2. M.Sc(N).,tutor.,Dept of community health nursing Karpaga Vinayaga college of nursing chinnakolambakkam,kancheepuram dt.

\section{Manuscript Info}

n......................

\section{Manuscript History}

Received: 05 April 2019

Final Accepted: 07 May 2019

Published: June 2019

Key words:-

Effectiveness, Structured teaching programme, , knowledge ,expressed practice, sanitary napkin.Menarche.

\section{Abstract}

Background: School life is the first experience of living outside the home which mould the school children to prepare themselves to lead a life, according to their growth and development and changing needs of the society. The personal hygiene is the fundamental step for the children to learn in order to prevent diseases and promote health .Thus menstrual hygienic practices are greatly emphasized among school girls in order to promote the reproductive health, which also improves the girls self-image and promote their attitude towards good reproductive health.

Objectives Of The Study: 1.To assess the level of knowledge and expressed practice regarding sanitary napkin among school girls those who attained menarche.2.To evaluate the effectiveness of structured teaching programme on knowledge and expressed practice regarding sanitary napkin among school girls those who attained menarche.3.To associate the selected demographic variables and health related variables with the level of knowledge and expressed practice regarding sanitary napkin school girls those who attained menarche .

Methodology: A quantitative research approach was used for this study.A pre experimental one group pre and post-test design was chosen. The study was conducted among school girls those who attained menarche aged between 12 and14 years and studying in VIII (or) IX standard in Govt.girls higher secondary school at Acharapakkam in Kancheepuram district. A purposive sampling technique was adopted. A sample of 50 school girls who were studying VIII (or) IX standard and aged between 12 and 14 years at Govt. girls higher secondary school .self structured questionnaire was used to assess the knowledge regarding sanitary napkin.

Results: The paired " $t$ " value on comparison of pre and post test scores of level of knowledge and expressed practice regarding sanitary napkin within study participant unveiled the statistically significant difference at level $\mathrm{P}<0.001$. There was a statistically significant association of occupational status of father with level of knowledge regarding sanitary napkin among study participants at level $\mathrm{P}<0.05$. There was a statistically significant association of frequency of changing napkin 
with level of knowledge among study participants regarding sanitary napkin at level $\mathrm{P}<0.05$. The study finding proved that the structured teaching programme administered by the researcher was effective to increase the knowledge and practice regarding sanitary napkin among school girls.

Copy Right, IJAR, 2019,. All rights reserved.

\section{Introduction:-}

School life is the first experience of living outside the home which mould the school children to prepare themselves to lead a life, according to their growth and development and changing needs of the society. The personal hygiene is the fundamental step for the children to learn in order to prevent diseases and promote health. Each child undergo many changes when the growth and development takes place over a period of time. These development changes are common among both girls and boys; one of such physiological changes among girl is attaining menarche. It marks beginning of a multitude of physical, physiological and psychological changes in the lives of the adolescent girls. Generally menarche

According to the report by UNICEF (2016) there are 243 million adolescence comprising $20 \%$ of total population in India, which clearly shows that India has got more young people. It includes $10 \%$ of school girls aged between 12 to 14 years and majority of them lives, in rural areas. They do not know to take care of themselves in hygienic way during the time of menstruation which adversely affects their health. .

Thus menstrual hygienic practices are greatly emphasized among school girls in order to promote the reproductive health, which also improves the girls self-image and promote their attitude towards good reproductive health. It also avoids the embarrassment of staining their cloth and promote their self-respect among their friends. Good menstrual hygiene enhances their confidence and promote the regular school attendance and prevent environmental pollution.

\section{Statement of the Problem}

A study to assess the effectiveness of structured teaching programme on knowledge and expressed practice regarding sanitary napkin among school girls those who attained menarche at a selected school in Kancheepuram District.

\section{Objectives of the Study}

1. To assess the level of knowledge and expressed practice regarding sanitary napkin among school girls those who attained menarche.

2. To evaluate the effectiveness of structured teaching programme on knowledge and expressed practice regarding sanitary napkin among school girls those who attained menarche.

3. To associate the selected demographic variables and health related variables with the level of knowledge and expressed practice regarding sanitary napkin among school girls those who attained menarche

\section{Methodology:-}

A quantitative research approach was used for this study.A pre experimental one group pre and post-test design was chosen .The study was conducted among school girls those who attained menarche aged between 12 and14 years and studying in VIII (or) IX standard in Govt.girls higher secondary school at Acharapakkam in Kancheepuram district. The school was located at semi urban area in Kancheepuram District. The school comprised of classes starting from VI to XII standard. Total strength of the student in the school was 900that included 258 students in VIII and IX Standard.A total of 50 school girls were selected for the study by adapting purposive sampling technique.

The total score were computed and categorized as follows.

\begin{tabular}{|c|l|c|}
\hline Score & Level of knowledge in percentage & Category \\
\hline$<10$ & Inadequate Knowledge & $<50 \%$ \\
\hline $11-15$ & Moderately adequate knowledge & $51-75 \%$ \\
\hline $16-20$ & Adequate knowledge & $>76-100 \%$ \\
\hline
\end{tabular}




\section{Part-I}

It consisted of check list which contains ten items and it has a minimum score of ' 10 ' and maximum of ' 20 '. A score were interpreted as follows;

\begin{tabular}{|c|c|c|}
\hline Score & Level of practice in percentage & Category \\
\hline$<10$ & $<50 \%$ & Poor practice \\
\hline $11-15$ & $51-75 \%$ & Good practice \\
\hline $16-20$ & $>76-100 \%$ & Excellent practice \\
\hline
\end{tabular}

TABLE - 1

Distribution of level of expressed practice regarding sanitary napkin among school girls in pre and post test $\mathbf{N}=\mathbf{5 0}$

\begin{tabular}{|c|c|c|c|c|c|}
\hline \multirow[t]{2}{*}{ S.NO } & \multirow[t]{2}{*}{ Level of practice } & \multicolumn{2}{|c|}{ Pre-test } & \multicolumn{2}{|c|}{ Post-test } \\
\hline & & $\mathbf{N}$ & $\%$ & $\mathbf{N}$ & $\%$ \\
\hline 1 & Inadequate practice & 42 & 84 & 5 & 10 \\
\hline 2 & Moderately adequate practice & 8 & 16 & 12 & 24 \\
\hline 3 & Adequate practice & - & - & 33 & 66 \\
\hline & Total & 50 & 100 & 50 & 100 \\
\hline
\end{tabular}

The above table reveals that $42(84 \%)$ and $8(16 \%)$ if studygirls participants had inadequate and moderately adequate practice respectively in pre test. In post-test $33(66 \%)$ and $12(24 \%)$ had adequate practice and moderately adequate practiceand only $5(10 \%)$ had inadequate knowledge among study participants respectively.

Table 2:-Comparison of pre and post-test knowledge score regarding sanitary napkin among school girls

\begin{tabular}{|l|l|c|c|c|c|}
\hline S.NO & \multicolumn{1}{|c|}{ Observation } & Mean & SD & Paired 't' value & p-value \\
\hline 1 & Pre-test & 6.62 & 1.86 & $38.339 * * *$ & 0.001 \\
\hline 2 & Post-test & 17.9 & 1.23 & & \\
$* * * \mathrm{P}<0.001$
\end{tabular}

The above table unveils that there was a statistically significant difference between pre and post knowledge score regarding sanitary napkin among school girls at $\mathrm{P}<0.001$.

Table 3:-Comparison of pre and post-test expressed practice score regarding sanitary napkin among school girls

\begin{tabular}{|l|l|c|c|c|c|}
\hline S.NO & Observation & Mean & SD & Paired 't' value & p-value \\
\hline 1 & Pre-test & 6.48 & 3.62 & $13.504 * * *$ & 0.001 \\
\hline 2 & Post-test & 15.52 & 2.59 & & \\
\hline$* * \mathrm{P}<0.001$
\end{tabular}

The above table illustrates that there was a statistically significant difference test between pre and post-test expressed practice score regarding sanitary napkin among school girls at $\mathrm{P}<0.001$.

\section{Results:-}

The paired " $t$ " value on comparison of pre and post test scores of level of knowledge and expressed practice regarding sanitary napkin within study participant unveiled the statistically significant difference at level $\mathrm{P}<0.001$.There was a statistically significant association of occupational status of father with level of knowledge regarding sanitary napkin among study participants at level $\mathrm{P}<0.05$. There was a statistically significant association of frequency of changing napkin with level of knowledge among study participants regarding sanitary napkin at level $\mathrm{P}<0.05$. The study finding proved that the structured teaching programme administered by the researcher was effective to increase the knowledge and practice regarding sanitary napkin among school girls

\section{Nursing implication}

The findings of the study has implication in different field of nursing that is nursing practice, nursing education, nursing administration and nursing research. 


\section{References:-}

1. Annamma Jacob, (2005). A ComprehensiveText book of Midwifery. $2^{\text {nd }}$ edition. Jaypee Brothers Medical Publishers, New Delhi;

2. Abdulla, F.G., \& Levine (1986). Better Nursing Care through Nursing research. $11^{\text {th }}$ edition. Mac Million Company, London;

3. Basvanthappa, B.T. (2013). Text Book of Nursing Research. $3^{\text {rd }}$ edition. Jaypee Brothers Medical Publishers, New Delhi;

4. Burns,N. \& Groove. S.K. (1995). Understanding Nursing Research. $2^{\text {nd }}$ edition. Philadelphia; Harcourt Publishers.

5. Julia, B. \& George. (1990). Nursing Theories - The Bare Professional Practice. $4^{\text {th }}$ edition. Connecticut Publications. 